\title{
A Tracer Study of Bachelor of Science in Information Technology(BSIT) Graduates of Nueva Ecija University of Science and Technology (NEUST), San Isidro Campus
}

\author{
Jennilyn C. Mina ${ }^{1}$, Ellen Jane G. Reyes ${ }^{2}$, Rodella F. Salas ${ }^{3}$
}

${ }^{1}$ On-the-Job Training Coordinator, NEUST San Isidro Campus, Philippines

${ }^{2}$ Faculty Member, College of Information and Communications Technology, Philippines

${ }^{3}$ Chairman, College of Information and Communications Technology, Philippines

\begin{abstract}
It has been a practice of every higher educational institution to follow up on their graduates through tracer studies. This study generally aimed to trace the up-to-date status and employment of the BSIT graduates of Nueva Ecija University of Science and Technology, San Isidro Campus for the Academic Year 2016-2017 and Academic Year 2017-2018. The descriptive method of research was used with a modified questionnaire as the major data-gathering instrument. There were 249 total graduates but only 219 of them responded to the study which involved 122 males and 97 females. Descriptive statistics such as frequency counts, percentages, and ranking were used in this study.

This study aimed to determine the general profile, educational background, professional examinations passed after college, employment profile, and reasons for unemployment of the unwaged respondents. Based on the tallied results, there is a high rate of employability with regular/permanent status among BSIT graduates. This means that the BSIT curriculum is aligned with the needs of the industry. The researchers have suggested an establishment of a partnership with the Civil Service Commission and other IT companies to assist the BSIT graduates in applying and passing eligibility for them to get the security of tenure and a higher salary.
\end{abstract}

Keywords- Employment, graduates, information technology, tracer study.

\section{INTRODUCTION}

In the Philippines, holding a diploma is a huge achievement. It is considered the ultimate dream of every parent for their children. Acquiring that piece of paper reflects one of the parents' hidden desires to be recognized by others (Klein, 2014). It is deemed as a symbol of hard work being paid off. A diploma is more than just a piece of paper; it is the most valuable thing a graduate will receive during his graduation rites. That "simple piece of paper" is a badge and confirmation of a student's success and achievement (Fortich-Poblete, 2019).

The biggest challenge comes after receiving a college diploma; it is employment. Making the shift from university to post-graduation life is one of the most electrifying stages of life (Petersen, 2016). Most of the graduates frequently face difficulties when making the transition from student life to the career world. The workplace is ever-changing. At the current state, employers typically offer short-term contracts and project-based work, while applicants are more particular on job security, higher wages, and better work conditions (Ow, 2019).

Everyone has experienced the complexities in job searching, but it does not end there (Ponce, 2019). When hired, the challenge goes along during training, and the integration into the workforce of your new job arises. But as graduates of higher educational institutions, they must show the world that job-hunting is not a dilemma (Balingbing, 2014).

As there are fewer assurances about what career a college degree will lead to, employers want graduates who are better prepared for the workplace (Docherty, 2014). Studentgraduates are expected to earn a sense of expertise in their chosen field and must build confidence to discover newfound possibilities and brand-new employment especially nowadays that competition has become a daily breakfast (Mathed, 2008).

According to the Philippine Statistics Office (2019), the employment rate in April 2019 was estimated at 94.9 percent. The unemployment rate in April 2018 was 5.5 percent. Among the regions, Autonomous Region in Muslim Mindanao (9.0\%), National Capital Region (6.3\%), Ilocos Region (5.9\%), and Bicol Region (5.8\%) were the regions with the highest unemployment rates. Luckily, Region III where Nueva Ecija is located was not part of this highest unemployment rate.

From the aforementioned figures, it is evident that every university should conduct a tracer study to assess if the programs being offered are matched within the labor force and at the same time, to verify if the graduates are competent 
enough in their respective disciplines. On the other hand, a tracer study is a perfect tool in providing an obvious indication of course outcomes as it permits universities to map the paths of their graduates (Fisher and Chapman, 1995). Thus, the findings of this study will enable the institution's curriculum planner to evaluate the effectiveness of the academic programs being offered by the university (Kongmanus 2016).

The Nueva Ecija University of Science and Technology (NEUST) San Isidro Campus started offering a Bachelor of Science in Information Technology (BSIT) program since the year 1999, and every year the campus is producing nearly hundreds of graduates. Thus, this study aimed to determine the employability of BSIT graduates of A.Y. 2016-2017 and A.Y. 2017-2018. This study was conducted because it is believed by the researchers that producing graduates equipped for their future is every higher education institution's (HEI's) key responsibility (Aclan, Saban, Famerong and Francisco, 2018).

\section{OBJECTIVES OF THE STUDY}

The main objective of the study was to trace the BSIT graduates of NEUST San Isidro Campus of A.Y. 2016-2017 and A.Y. 2017-2018.

Specifically, this tracer study sought to answer the following questions:

1. What is the general profile of the respondents in terms of:

1.1 Year Graduated;

1.2 Gender;

1.3 Civil Status; and,

1.4 Present Location.

2. What is the educational background of respondents in terms of:

2.1 Professional examination/s passed.

3. What is the employment profile of the employed respondents regarding:

3.1 Duration to land their first job;

3.2 Present employment status; and,

3.3 Monthly Salary.

4. What is the employment profile of the unemployed respondents regarding:

4.1 Reason/s for unemployment.

\section{METHODOLOGY}

The researchers used the descriptive method of research. Descriptive research can be explained as a statement of affairs as they are at present with the researchers having no control over variables. Moreover, this type of study can be characterized as simply the attempt to determine, describe, or identify what is (Ethridge, 2004). In addition to that, descriptive research is directed at casting light on current issues or problems through a process of data collection that enables them to describe the situation more completely than was possible without employing this method (Fox and Bayat, 2007).

The respondents of the study were the eighty-one (81) BSIT graduates of A.Y. 2016-2017 and one hundred thirty-eight (138) graduates of A.Y. 2017-2018 with a total of 219 graduates. The researchers used a modified Commission on Higher Education Graduate Tracer Survey designed in Google form. The modified questionnaire consists of four parts namely: general information, educational background, employment profile, and reason/s for unemployment. The modified questionnaire was planned and created by the researchers. Suggestions for modifications and improvements were done and it was set for a dry run and got tested by selected BSIT students.

The researchers extract the data of BSIT graduates with personal information from the Registrar's Office of the campus. After getting the list, the link https://tinyurl.com/bsit-tracer16-18 was disseminated to CICT NEUSTSIC closed group, graduates' email account, group chat, and messenger to gather data. Upon completion of the data gathering procedure, responses were tabulated to facilitate the analysis during the interpretation of data. The data gathered were tallied, analyzed, and interpreted. Descriptive statistics such as frequency counts, percentages, and ranking were used in this study.

\section{RESULTS AND DISCUSSION}

This part provides the presentation of data relevant to the objectives of the study. Corresponding analysis and interpretation regarding the presented data were discussed using the above-cited statistical tools. 


\section{Figure 1. Distribution of Respondents per Academic Year}

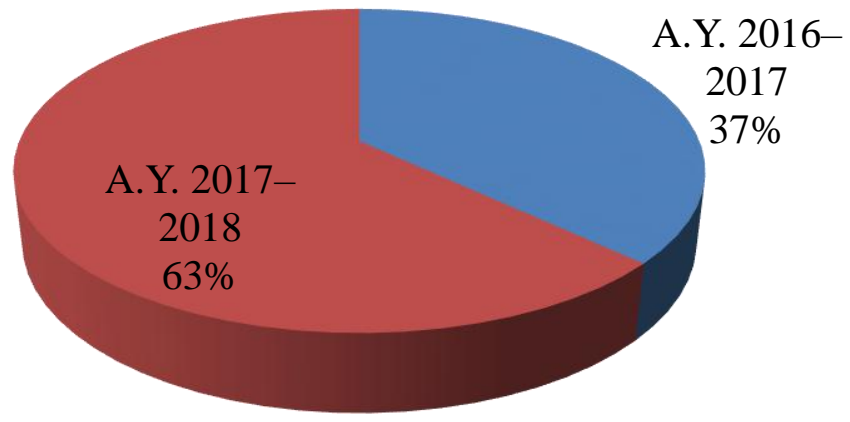

The distribution of the respondents per academic year is shown in the illustration above. It can be observed from the data above that majority of the respondents who answered the survey were from the graduates of A.Y. 2017-2018 which is $63.00 \%$ of the population and it is believed by the researchers that this figure is enough to represent the whole population and give a wellrounded employability results which can be used in the assessment of BSIT curriculum for future improvement and development.

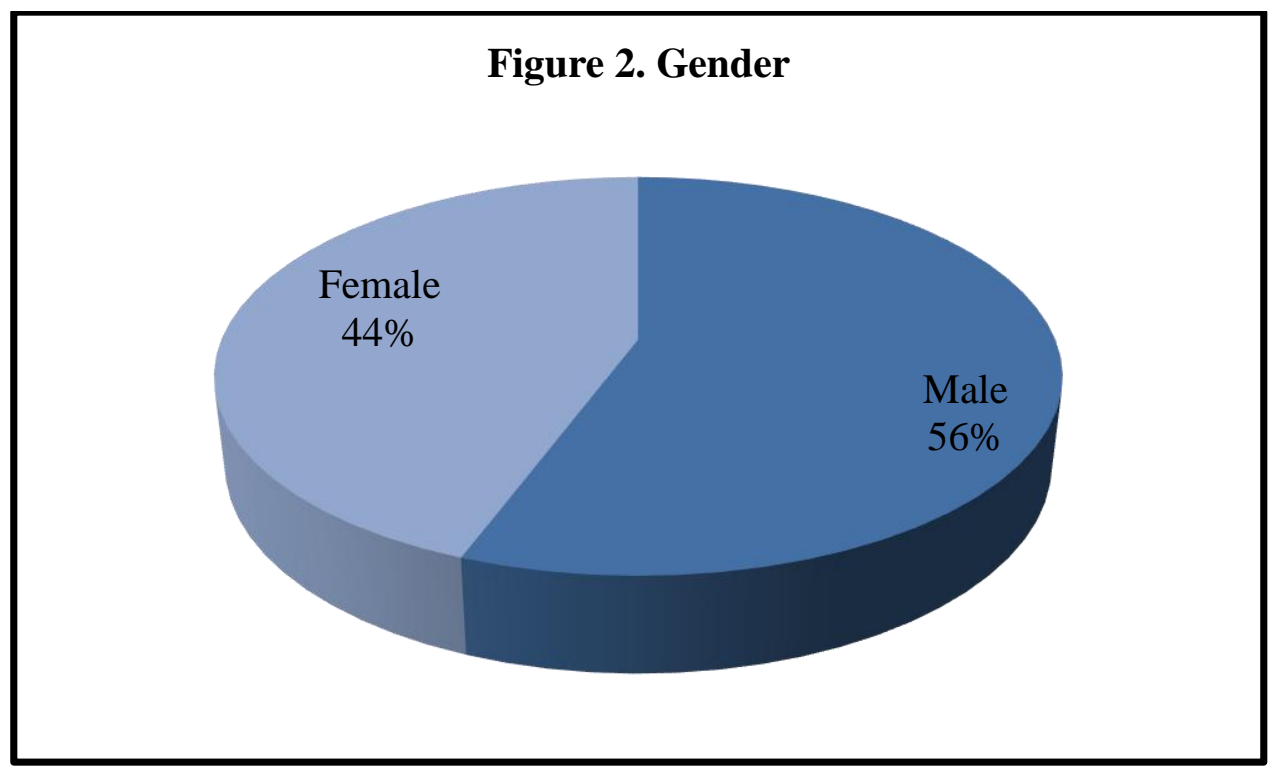

The illustration above has shown the gender of graduate-respondents. It can be noted that majority of the respondents or 56.00\% were male but it is also noticeable that the composition of the respondents is favorable as both sexes are sufficiently represented considering that the distribution is almost equal (Sagarino, Moreno, Juan, Langomez, Tagiobon, Palmes and Cabigas, 2017).

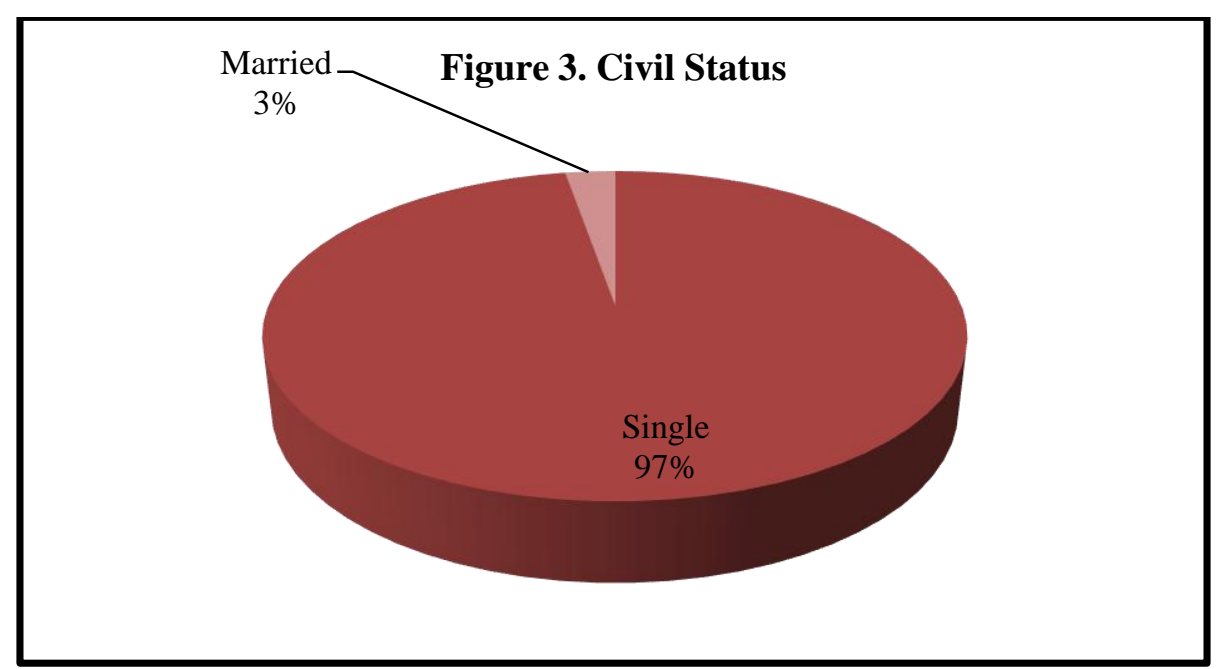

The illustration above has shown the civil status of the graduate-respondents. Notably, the majority of the respondents, or $97.00 \%$ were still single. The graduates are ruled by singles for the reason that most of them are still in the age bracket of 20 to 30 years old (Sagarino, Moreno, Juan, Langomez, Tagiobon, Palmes and Cabigas, 2017). Since most of the respondents are millennials, it is considered that the reason behind being single is they are focusing on their careers (Lusinski, 2018). 


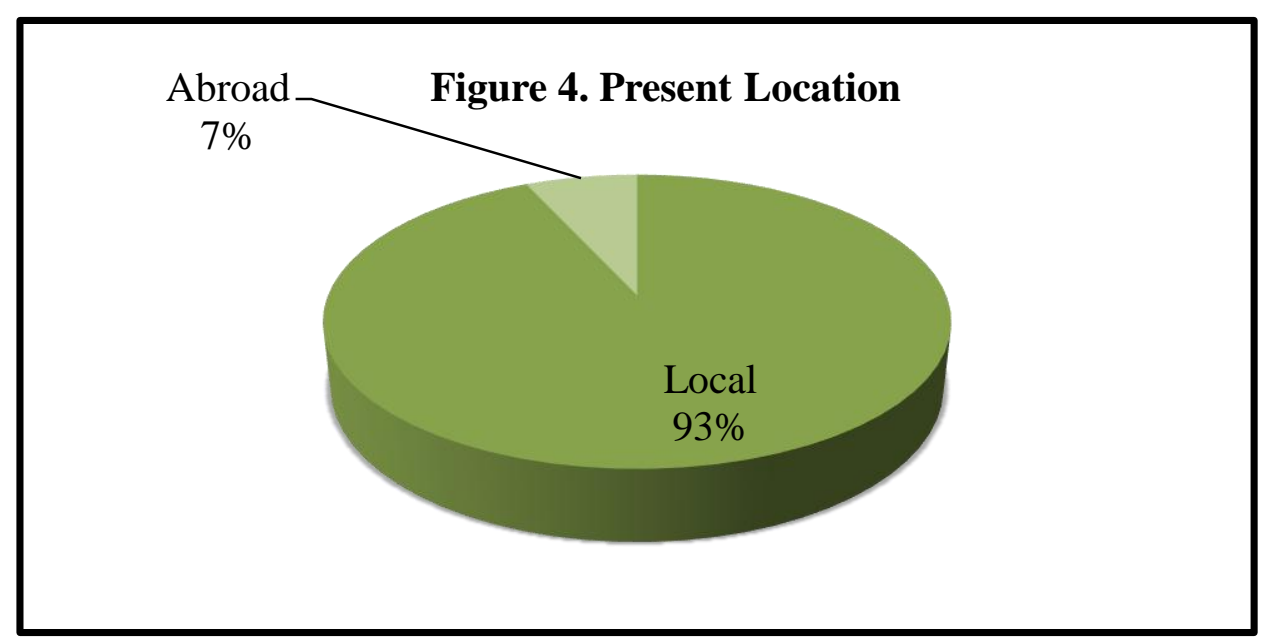

The illustration above has shown the present location of the graduate-respondents. It is noteworthy that the majority of the respondents or $93.00 \%$ are currently staying in the country. It is revealed that there is a huge increase in IT opportunities in the country (McAuliffe, 2015). Results of an online survey showed that three out of four locally employed Filipinos would accept jobs in their home region rather than work in another part of the country $(\mathrm{Uy}, 2016)$.

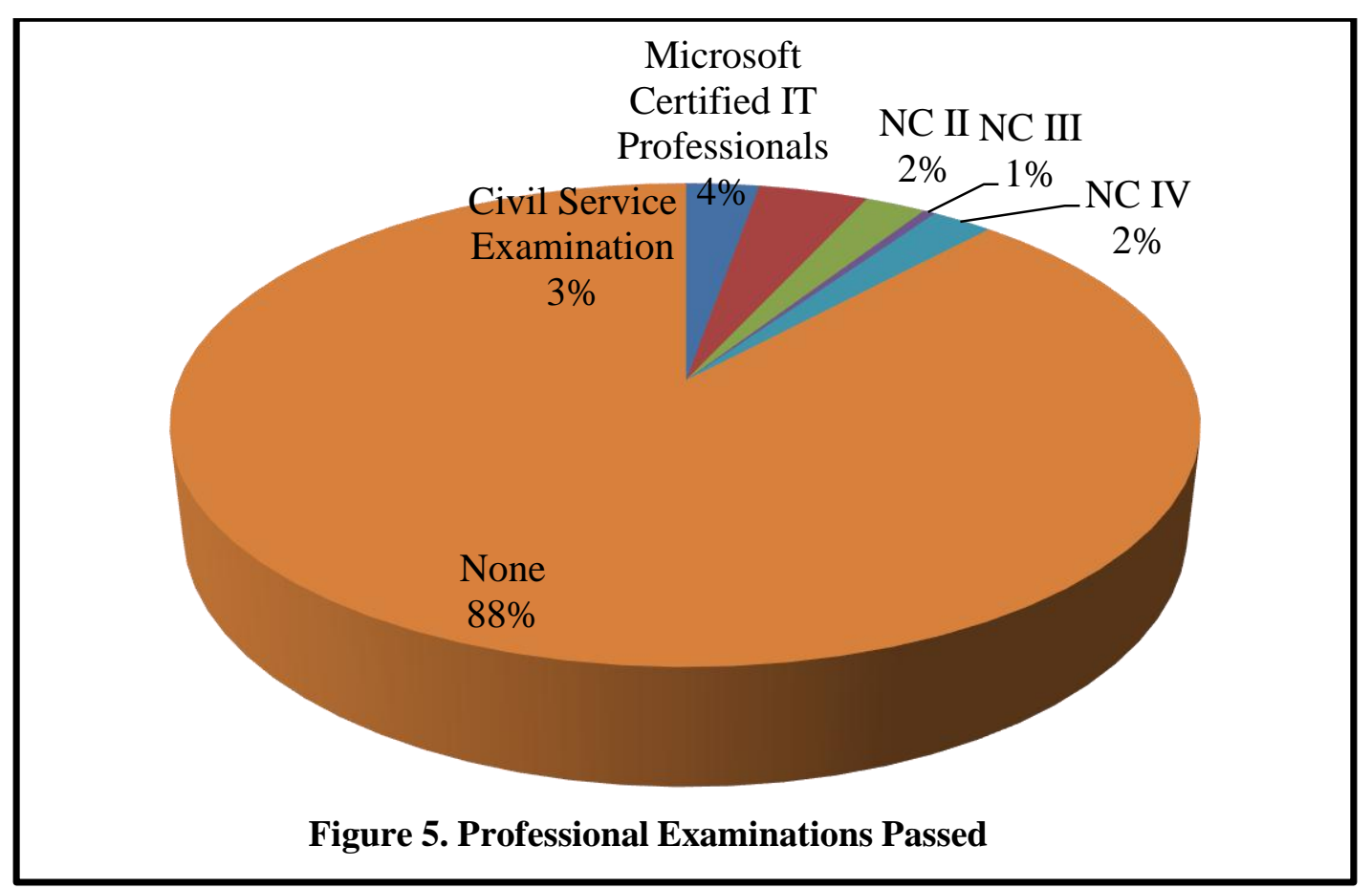

The illustration above has shown the professional examinations passed by the graduate-respondents. A great number of graduates or $88.00 \%$ did not take or pass any professional examinations. It is advised by the university that graduates take professional examinations that may be used for securing employment in the government (Balingbing, 2014). 


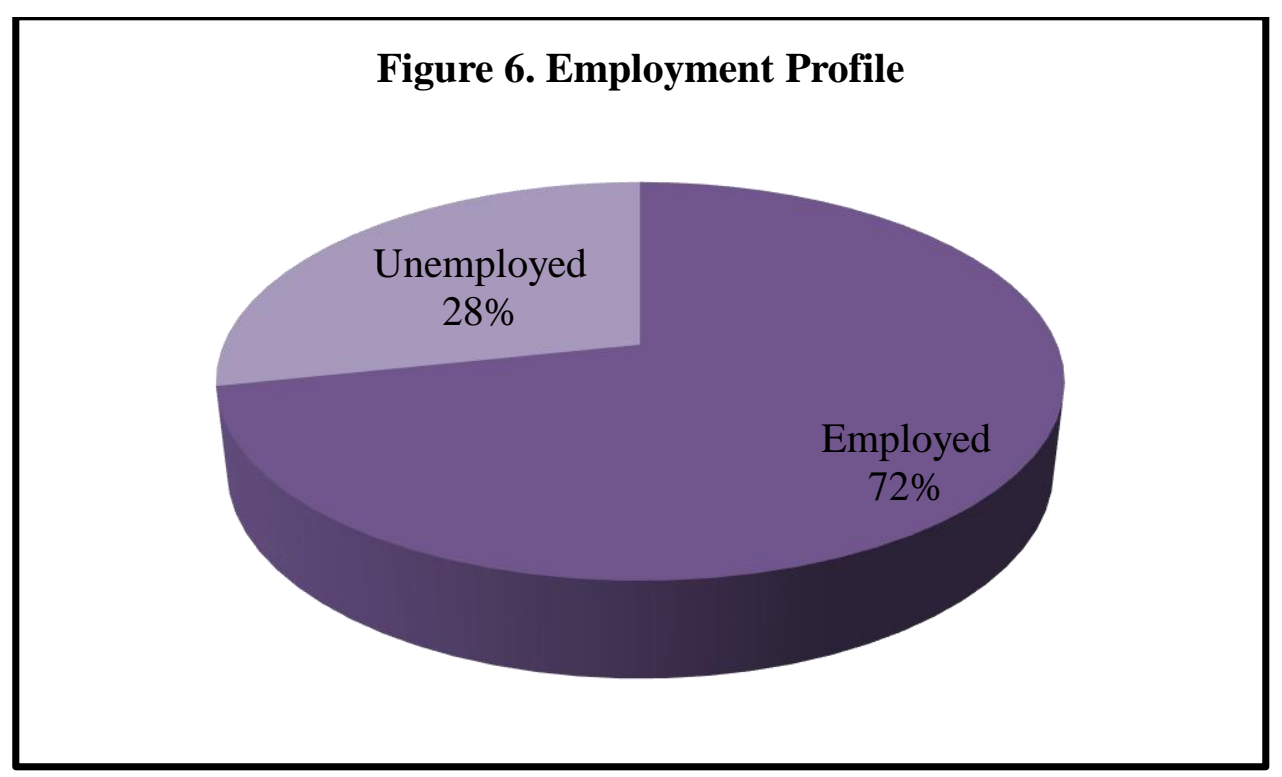

The illustration above has shown the employment profile of the graduate-respondents. The majority of the graduates or $72.00 \%$ are currently employed. This implies that the majority of the graduates tried their very best to employ themselves after receiving their college diploma (Galila-Infante, Junco and Marquez, 2014).

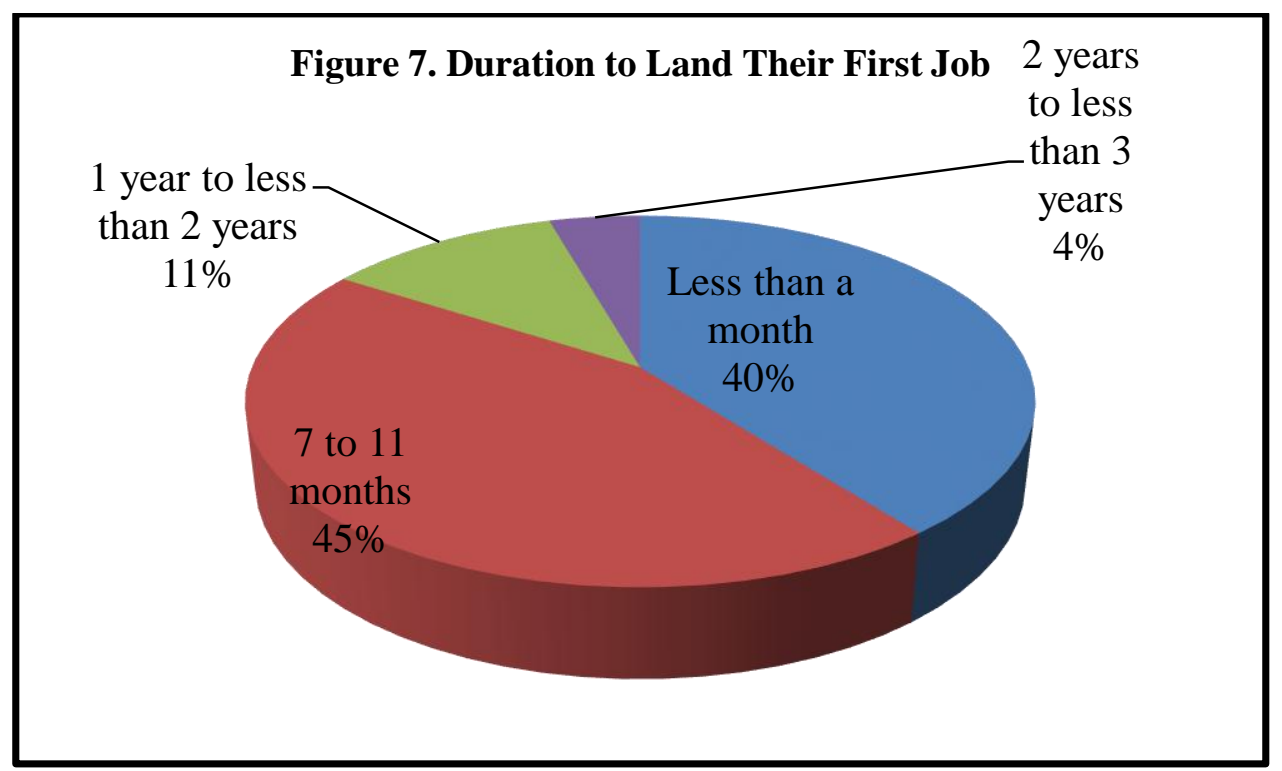

The illustration above has shown the duration before the graduate-respondents got hired in their first job. The majority of the graduates or $45.00 \%$ had to wait 7 to 11 months before they finally get hired. Graduates took a long time before they landed on their first job. In this case, it can be inferred that the period of seeking a job depends also on the availability of vacancies and the industry (Aydinan, 2019).

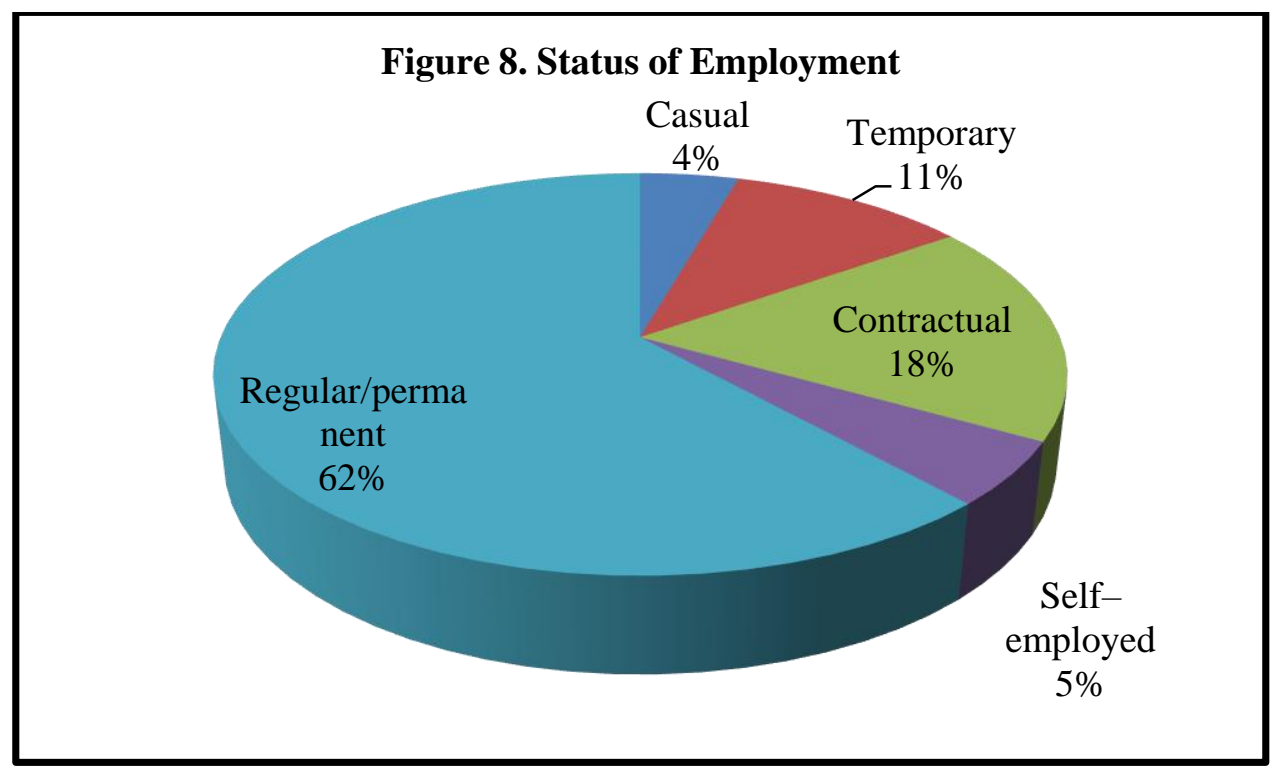


The illustration above has shown the status of employment of the graduate-respondents who are presently employed. The majority of the 157 employed graduates or $62.00 \%$ are currently in permanent/regular status. This denotes that majority of them are enjoying the regular status or full-time job (Laguador and Dotong, 2013).

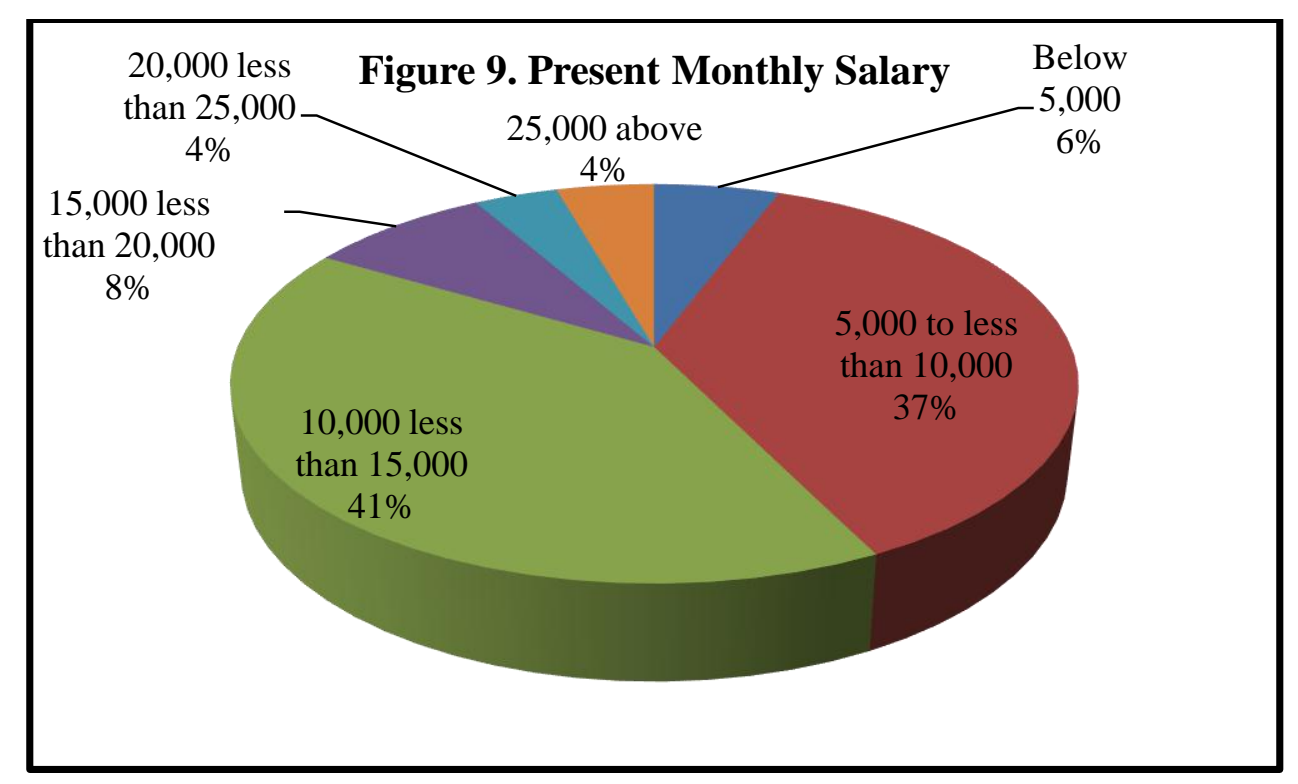

The illustration above has shown the present monthly salary of the graduate-respondents who are presently employed. The majority of the 157 employed graduates or $41.00 \%$ are receiving a monthly salary which is ranging from $\mathrm{P} 10,000.00$ to $\mathrm{P}$ $15,000.00$. These results imply that these employed-respondents are currently receiving a meager salary, compensation, and other privileges that cannot cover all their daily expenses. As quoted, "a family of five needed at least P 5,590.00 on the average every month to meet basic food needs last year, and at least P 8,022.00 on the average monthly to meet both basic food and nonfood needs, for the current year" (Rappler, 2014).

Table 1. Reasons for Unemployment

\begin{tabular}{|c|l|c|c|c|}
\hline No. & Reasons for Unemployment & Frequency & Percentage & Rank \\
\hline 1 & Advance or further study & 9 & $14.52 \%$ & 3.00 \\
\hline 2 & Family Concern & 11 & $17.74 \%$ & 1.00 \\
\hline 3 & Health-Related Reason & 9 & $14.52 \%$ & 3.00 \\
\hline 4 & Lack of Work Experience & 9 & $14.52 \%$ & 3.00 \\
\hline 5 & No Job Opportunity & 4 & $6.45 \%$ & 7.50 \\
\hline 6 & Did not look for a job & 2 & $9.68 \%$ & 6.00 \\
\hline 7 & Left my last job to pursue better opportunity abroad & 8 & $6.45 \%$ & 7.50 \\
\hline 8 & End of Contract $\quad \mathbf{6 2}$ & $\mathbf{1 0 0 . 0 0 \%}$ & \\
\hline 9 & I have my own business & 6.00 \\
\hline \multicolumn{2}{c}{ Total } & & & 5.00 \\
\hline
\end{tabular}

When the unemployed graduates were asked for their reasons why they were not employed at the time of the conduct of this study, the majority of them mentioned family concern related reasons (17.74\%). This was followed by advance or further study; health-related reasons and lack of work experience $(14.52 \%)$. It was also stated by some unwaged that having their own business (12.90\%), did not look for a job $(9.68 \%)$, no job opportunity and end of the contract (6.45\%), and just recently left their last job to pursue better opportunity abroad (3.23\%) as other reasons why they were unemployed. This implies that those who were unemployed cannot perform dual-tasks and they need to prioritize one from the other (Galila-Infante, Junco and Marquez, 2014).
It's impossible to be a great parent and a great employee or entrepreneur at the same time. One should pick either a career or a family (Financial Samurai, 2020). This is true to everybody unless one is capable of paying a caregiver. In reality, there are many difficulties every graduate may come across in their quest towards landing in a job related to their field of specialization. What is sure about it is that graduates are ought to meet these challenges along the way.

\section{CONCLUSION AND RECOMMENDATION}

The employment rate of the Bachelor of Science in Information Technology at San Isidro Campus is a great 
manifestation of the effectiveness of the program being offered by the university. BSIT graduates are found to be employable and this study aimed to enhance the program to increase the future employment rate of the students who are also taking the same course. After collecting all the data needed, the researchers found out that the majority of the graduates were male, single, locally employed, and did not take or pass any professional examinations. It was also realized by the researchers that the majority of them landed their job seven to eleven months after graduation. It is also good to know that employed graduates were regular/permanent in their current job. Unluckily, a great number of respondents were just earning $\mathrm{P} 10,000.00$ to $\mathrm{P}$ $15,000.00$ monthly salary. It was also understood that some respondents were unemployed and most of them gave family-related concerns as their reasons.

It is therefore recommended that the campus specifically the College of Information and Communications Technology must strengthen the functions of the existing student organizations to boost student's participation and cooperation in taking the lead to plan, organize, direct and implement programs that are essential for the growth and development of the students (Mina and Aydinan, 2019) as a preparation for their future employment. It is also suggested by the researchers to create career guidance and placement program for students before taking up to their major fields and initiate forums with the students before admission together with their parents and teachers for the right career choice. The university should establish a partnership with the Civil Service Commission and other IT companies to assist the BSIT graduates in applying and passing eligibility for them to get the security of tenure and a higher salary. Also, a qualitative tracer study for purposively chosen (Subia, 2020) participants who rise from rags to riches may be conducted to further strengthen the research output in this program. Lastly, the university should continue conducting grand alumni homecoming and per campus alumni homecoming to consistently keep in touch, to enhance the interests (Subia, 2019) of the graduates andbe updated on the alumni of the BSIT program consistently.

\section{REFERENCES}

[1] Klein, Stephen (2014). Receiving a Diploma or Degree Dream Symbol. Retrieved on October 27, 2019, from: http://dreamstop.com/receiving-diploma-degree-dreamsymbol/

[2] Fortich-Poblete, Maia (2019). The Toga, Cap, Hood, and Diploma: What Do These Graduation Symbols Mean? Retrieved on September 19, 2019 from: https://mindanaogoldstardaily.com/the-toga-cap-hood-anddiploma-what-do-these-graduation-symbols-mean/

[3] Petersen, Julie (2016). 6 Career Challenges You'll Face as a Recent College Graduate. Retrieved on November 04, 2019 from: https://www.recruiter.com/i/6-career-challenges-youllface-as-a-recent-college-graduate/

[4] Ow, Patrick (2019). Major challenges facing our young people, graduates and students today. Retrieved on December 13, 2019 from: https://thriveglobal.com/stories/major-challengesfacing-our-young-people-graduates-and-students-today/
[5] Ponce, Emily (2019). Challenges faced by graduates \& students in the workplace. Retrieved on January 09, 2020 from: $\quad$ https://motify.ca/articles/challenges-faced-bygraduates-students-in-the-workplace/

[6] Balingbing, Arly B. (2014). Tracer Study of BS in Information Technology (BSIT) Graduates of Camarines Sur Polytechnic Colleges, Nabua, Camarines Sur from 2004 to 2010. Asia Pacific Journal of Multidisciplinary Research, Volume 2, No. 4, P-ISSN 2350-7756, E-ISSN 2350-8442

[7] Docherty, David (2014). Universities must produce graduates who are ready for any workplace. Retrieved on November 14 , 2019 from: https://www.theguardian.com/higher-educationnetwork/2014/may/22/universities-must-produce-graduateswho-are-ready-for-workplace

[8] Matthed, J (2008). Professional Graduates. www.yahoo.com.sg/status of graduates/ 2009/report/1.23.2008.

[9] Philippine Statistics Authority (2019). Employment Rate in April 2019 is Estimated at 94.9 Percent. Retrieved on February 01, 2020 from: https://psa.gov.ph/content/employment-rateapril-2019-estimated-949-

percent\#: : :text=The\%20employment\%20rate\%20in\%20April, 96.0\%25)\%20(Table\%204)

[10] Fisher S., and Chapman, B. (1995). Conducting Tracer Studies in Adult Language and Literacy Programs: Teacher Education. The National Center for English Language Teaching and Research. Retrieved on February 23, 2020 from https://goo.gl/3zWwSr

[11] Kongmanus, K. (2016). Development of Project-Based Learning Model to Enhance Educational Media Business Ability for Undergraduate Students in Educational Technology and Communications Program. Journal of Advances in Humanities and Social Sciences 2(5): 287-296.

[12] Aclan, E, Saban, G.A., Famerong, J and Francisco, R. (2018). Tracer Study of AUP BEEd and BSED Graduates from 20122016. Journal of Education, Psychology, and Humanities (JEPH), ISSN 2599-5294

[13] Ethridge, D.E. (2004). Research Methodology in Applied Economics. John Wiley \& Sons, p. 24

[14] Fox, W. \&Bayat, M.S. (2007). A Guide to Managing Research. Juta Publications, p.45

[15] Sagarino, E., Moreno, E., Juan, T.J., Langomez, R., Tagiobon, R., Palmes, M.K. and Cabigas, R.A. (2017). A tracer study on the University of the Immaculate Conception graduates of bachelor of music. Journal of Advanced Research in Social Sciences and Humanities Volume 2, Issue 5 (298-310) DOI: https://dx.doi.org/10.26500/JARSSH-02-2017-0503

[16] Lusinski, Natalia (2018). 11 Most Common Reasons Young People Aren't In Relationships. Retrieved on March 16, 2020 from: https://www.bustle.com/p/11-most-popular-reasonsmillennials-are-single-according-to-a-new-survey-8385620

[17] McAuliffe, Nora Ide (2015). Life after you graduate: what are the best options for you? Retrieved on March 22, 2020 from: https://www.irishtimes.com/news/education/life-after-yougraduate-what-are-the-best-options-for-you-1.2371010

[18] Uy, Jocelyn R. (2016). 3 out of 4 Filipinos prefer to work in hometowns. Retrieved on March 21, 2020 from: https://newsinfo.inquirer.net/776677/3-out-of-4-filipinosprefer-to-work-in-hometowns

[19] Galila-Infante, J., Junco, E. and Marquez, M. (2014). Employment Status of the Graduates of Guimaras State College, Philippines. IAMURE International Journal of Multidisciplinary Research, Vol. 11. October 2014, Print ISSN 2243-8327 Online ISSN 2244-0429 doi: http://dx.doi.org/10.7718/iamure.v11i1.907 
[20] Aydinan, Januaryn Jose B. (2019). Employment Array of Bachelor of Science in Criminology Graduates in Nueva Ecija University of Science and Technology. International Journal of English, Literature and Social Sciences (IJELS) Vol-4, Issue6, ISSN: 2456-7620 https://dx.doi.org/10.22161/ijels.46.16

[21] Laguador, Jake M. and Dotong, Conrado I. (2013). Tracer Study of BS Computer Engineering Graduates of Lyceum of the Philippines University. International Journal of Management, IT and Engineering, Volume 3, Issue 8 ISSN: 2249-0558

[22] Rappler (2014). NEDA: Poverty Likely Worsened in 2013 due to Yolanda. Retrieved on May 24, 2020 from http://goo.gl/Cmmz36

[23] Financial Samurai (2020). Career or Family? You Only Need To Sacrifice For 5 Years At Most. Retrieved on April 28, 2020 from: https://www.financialsamurai.com/career-family-give5-years-life/

[24] Mina, Jennilyn C. and Aydinan, Januaryn Jose B. (2019). Trainers' Feedback on the Performance of Bachelor of Science in Criminology during their On-The-Job Training in the TriBureau in the Province of Nueva Ecija. International Journal of English, Literature and Social Science (IJELS) Vol-4, Issue-4, ISSN: 2456-7620 https://dx.doi.org/10.22161/ijels.44.44

[25] Subia, G. S. (2020). Treasure Chess: Worthy Contributions of the Gamein the Lives of Student Champions. The Normal Lights, 14(1),100-121.

[26] Subia, G. S. (2020). Fortuitous: A proposed activity-basedbook in mathematics of chance. International Journal of Scientific and Technology Research, 9(3), 450-453. 